\title{
The first record of a frogfish, Fowlerichthys scriptissimus (Antennariidae, Lophiiformes), from Korea
}

\author{
Song-Hun Han ${ }^{1}$, Joon Sang Kim² and Choon Bok Song ${ }^{3^{*}}$
}

\begin{abstract}
This is the first report of Fowlerichthys scriptissimus (Lophiiformes, Antennariidae) from Korea. A single specimen (291.0 mm SL) was collected off the coast of Jejudo Island by gill net on 28 March 2012 and identified with morphological and molecular approaches. The specimen is characterized by having all five pelvic fin rays bifurcate and possessing 20 vertebrae, 13 pectoral-fin rays, and a basidorsal ocellus on the side of the body. This species is distinguishable from other Korean taxa by the number of pectoral fin rays, the bifurcate form of the pelvic rays, and the vertebral count. We add this species to the Korean fish fauna and suggest new Korean names, "Byeol-ssin-beng-i-sok" and "Byeol-ssin-beng-i" for the genus and species, respectively.
\end{abstract}

Keywords: Fowlerichthys scriptissimus, Antennariidae, New record, Jejudo Island, Korea

\section{Background}

The frogfishes (Antennariidae), which belong to order Lophiiformes, occur in all tropical and subtropical seas except the Mediterranean Sea (Nelson 2006). Worldwide, the family includes 46 species in 13 genera (Arnold and Pietsch 2012) and four species in two genera in Korea (Kim et al. 2005; Kim et al. 2011). All members of Antenariidae have the first dorsal fin spine modified into a fishing pole (illicium) and gill openings below or behind the base of the pectoral fin (Nelson 2006; Arnold and Pietsch 2012). The genus Fowlerichthys was originally suggested by Barbour (1941) when he described the new species, Fowlerichthys floridanus. However, as some of his morphological descriptions were not clear, most ichthyologists regarded the genus Fowlerichthys as a synonym of Antennarius (Pietsch 1984; Senou 2002; Manilo and Bogorodsky 2003). Later, Arnold and Pietsch (2012) reconstructed evolutionary relationships within Antennariidae with molecular phylogenetics and recognized that Fowlerichthys as a valid genus. They demonstrated that it can be separated from Antennarius by having all five pelvic fin rays bifurcate instead of one in the genus Antennarius.

\footnotetext{
* Correspondence: cbsong@jejunu.ac.kr

${ }^{3}$ College of Ocean Sciences, Jeju National University, Jeju 63243, Korea

Full list of author information is available at the end of the article
}

A single specimen of Fowlerichthys scriptissimus, which is otherwise unknown from Korea, was collected in the coastal waters of Jejudo Island by gill net on 28 March 2012. Here, we describe the morphological characters of F. scriptissimus and report the results of a molecular barcode determination of the specimen's identification using the COI gene.

\section{Methods}

Counts and measurements followed the method of Hubbs and Lagler (1964). When conducting this study, we adhered to the ethical guideline of the International Council for Laboratory Animal Science (ICLAS) for researchers. The specimen was fixed in $10 \%$ buffered formalin and then transferred to $70 \%$ ethanol. Vertebrae were counted from radiographs (REX-525R, listem). The examined specimen was deposited at the Jeju National University (JNU), Korea, and is available from the corresponding author by reasonable request.

Total DNA was extracted from $25 \mathrm{mg}$ of the muscle tissue with an AccuPrep Genomic DNA Extraction Kit (Bioneer Inc.) according to manufacturer's protocol. The mitochondrial cytochrome $c$ oxidase subunit I (COI) gene was PCR-amplified with the primers, Asn-F1 (AAA HWC 
TTA GTT AAC AGC TAA) and Ser-R1 (GGG GTT CDA YTC CYC CCT TTC T). The polymerase chain reaction (PCR) was performed on a thermal cycler (TP600, Takara Bio Inc.) with a final volume of $40 \mu \mathrm{L}$ in a $0.2 \mathrm{~mL}$ PCR tube containing $10 \mathrm{mM}$ Tris- $\mathrm{HCl}(\mathrm{pH} 8.3), 50 \mathrm{mM} \mathrm{KCl}$, $2 \mathrm{mM} \mathrm{MgCl} 2,0.2 \mathrm{mM}$ dNTP mix, $0.5 \mathrm{mM}$ of each primer, $50 \mathrm{ng}$ template DNA solution, and $1 \mathrm{U}$ Ex Taq DNA polymerase (Takara Bio Inc.) The PCR cycles consisted of an initial denaturing step of $94{ }^{\circ} \mathrm{C}$ for $2 \mathrm{~min}$, followed by 30 cycles of $30 \mathrm{~s}$ at $94{ }^{\circ} \mathrm{C}$ for denaturation, $1 \mathrm{~min}$ at $54{ }^{\circ} \mathrm{C}$ for primer annealing, and $1 \mathrm{~min}$ and $50 \mathrm{~s}$ at $72{ }^{\circ} \mathrm{C}$ for extension, and an additional $7 \mathrm{~min}$ interval at $72{ }^{\circ} \mathrm{C}$ for a final extension. The PCR products were sequenced using the BigDye Terminator v3.1 Cycle Sequencing Kit (Applied Biosystems Inc.) and ABI PrismTM 3730XL DNA Analyzer. Sequencing reactions were conducted with the amplification primers in two directions. The DNA sequence obtained was deposited in the National Center for Biotechnology Information (NCBI) as GenBank accession number, KY195977. For molecular identification, we compared the specimen's COI sequence with the GenBank DNA sequences of the seven anglerfish species: Antennarius hispidus (FJ582855), Antennarius pictus (FJ582858), Antennarius striatus (AB282828), Histrio histrio (AB282829), Fowlerichthys avalonis (DQ0279840), F. scriptissimus (GU188480), and Lophius litulon (KJ020931). The DNA sequences were aligned and edited using Clustal W (Thompson et al. 1994) and BioEdit version 7 (Hall 1999). Genetic distances were calculated using MEGA 6 (Tamura et al. 2013) based on the Kimura two-parameter (K2P) model (Kimura 1980). A neighbor-joining (NJ) tree was constructed using the K2P model and 10,000 bootstrap replications in MEGA 6.

\section{Results}

Genus Fowlerichthys Barbour 1941

(New Korean genus name, Byeol-ssin-beng-i-sok)

Fowlerichthys Barbour 1941; 12 (type species, Fowlerichthys floridanus Barbour 1941). Arnold and Pietsch 2012,
128 (Rarotanga, Cook Islands); Stewart 2015, 886 (New Zealand).

The genus Fowlerichthys includes five species diagnosed by the following combination of characters: one or three darkly pigmented ocelli on side of body; illicium about as long as second dorsal spine; esca in form of tuft of slender filaments, a simple, oval-shaped appendage, escal pigment spots absent; dorsal rays 12-14 (usually 13); pectoral rays 11-14 (usually 12 or 13); all five pelvic rays bifurcate; anal rays $7-10$ (usually 8 ), all bifurcate; vertebrae 20 (Pietsch and Grobecker 1987; Arnold and Pietsch 2012).

\section{F. scriptissimus (Jordan 1902)}

(New Korean name, Byeol-ssin-beng-i) (Table 1; Fig. 1)

Antennarius scriptissimus Jordan, 1902, 373 (type locality, Bōsō Peninsula, Chiba Prefecture, Japan); Pietsch 2000, 597 (South China Sea); Senou 2002, 456 (Japan); Manilo and Bogorodsky 2003, S99 (Oman).

Antennarius sarasa Pietsch 1984, 36 (Japan); Araga 1984, 103 (Japan); Pietsch and Grobecker 1987, 123 (Réunion Island, New Zealand, and Philippines).

F. scriptissimus Arnold and Pietsch 2012, 128 (Rarotanga, Cook Islands)

\section{Material examined}

JNU-637, one specimen, $291.0 \mathrm{~mm}$ in standard length (SL), gill net, Hanlim-eup, Jeju-si, Jejudo Island, Korea, 28 March 2012.

\section{Description}

Meristic counts appear in Table 1. Measurements as a percentage of SL are as follows: body depth 67.6; body width 21.3; snout length 24.0; eye diameter 5.1; interorbital length 14.7; illicium length 6.9; first predorsal fin length 18.3; second predorsal fin length 20.1; third predorsal fin length 35.5; prepectoral fin length 36.7; preanal fin length 67.3; prepelvic fin length 9.5; length of second dorsal spine 8.4; length of third dorsal spine 10.8; length of pectoral fin ray 13.0; length of anal fin ray

Table 1 Morphological characters compared between the present specimen and previous studies on F. scriptissimus

\begin{tabular}{llllll}
\hline Morphological characters & Present study & Jordon (1902) & Araga (1984) & Pietsch and Grobecker (1987) & Senou (2002) \\
\hline Total length $(\mathrm{mm})$ & $350.0(n=1)$ & - & $350.0(n=1)$ & $-(n=5)$ & - \\
Standard length $(\mathrm{mm})$ & 291.0 & - & - & $99.0-280.0$ & \\
Count & $13(7)$ & III-12 & III-13 & $13(7-9)$ & 13 \\
$\quad$ Dorsal fin rays (bifurcate rays) & 13 & - & 13 & 5 & 13 \\
Pectoral fin rays & 1,5 & - & 5 & 8 & 1,5 \\
Pelvic fins rays & 8 & 8 & 8 & 9 & 9 \\
Anal fin rays & 9 & - & - & 9 \\
Caudal fin rays & & & & 9 \\
\hline
\end{tabular}




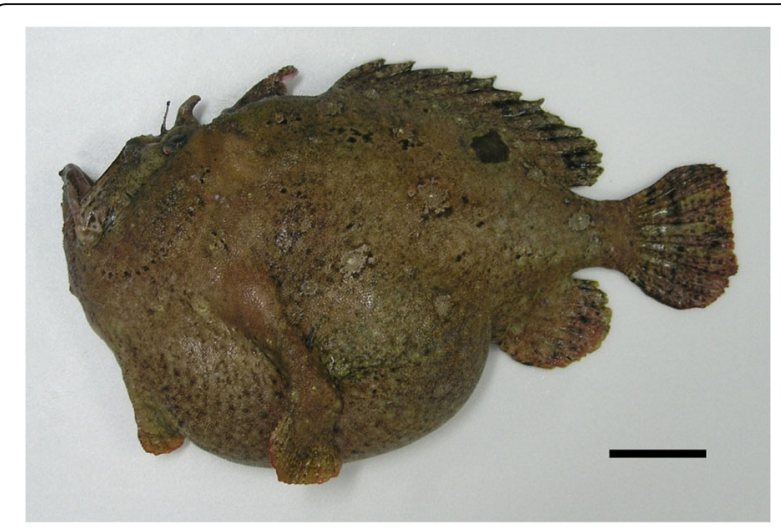

Fig. 1 F. scriptissimus (Jordan 1902), JNU-637, 291.0 mm SL, gill net, Hanlim-eup, Jeju-si, Jejudo Island, Korea. Scale bar $=50 \mathrm{~mm}$

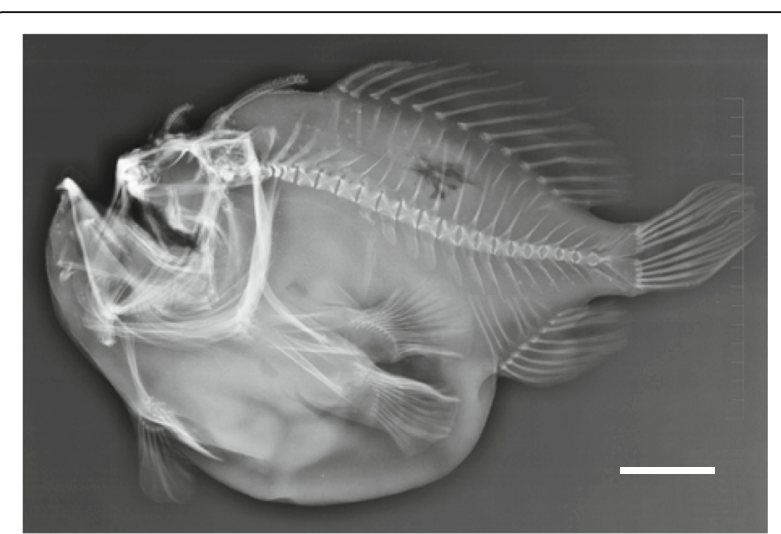

Fig. 2 Radiograph of JNU-637, F. scriptissimus. Scale bar $=50 \mathrm{~mm}$
12.5; caudal peduncle depth 12.1; and caudal peduncle length 9.2.

Body round and compressed; skin of body very rough and covered with close-set dermal spinules; head and eyes small; eyes lateral; mouth large and extremely oblique; first dorsal spine (illicium) shorter than second spine; esca simple and oval-shaped with a tuft; second and third dorsal spine rough and curved posteriorly; gill opening located below base of pectoral fin; depression between second and third dorsal spines; membrane behind second dorsal spine extending posteriorly, dividing area between second and third dorsal spines and nearly reaching to base of third (Fig. 3).

\section{Live coloration}

Whole body uniformly greenish brown; entire head, body, and fins with mottled dark brown reticulations except for inner surface of paired fins; a single, darkly pigmented, basidorsal ocellus on each side of body; scattered beige spots on body; esca with dark pigment at base.

\section{Color in preservative}

Body uniformly pale greenish brown; mottled dark brown spots and ocellus; beige spots no longer apparent.

\section{Distribution}

Widely known from Indo-West Pacific, including Réunion Island, New Zealand, the Philippines (Pietsch and Grobecker 1987), the Cook Islands (Arnold and Pietsch 2012), the South China Sea (Pietsch 2000), Japan (Jordan 1902; Pietsch 1984; Araga 1984), and Korea (Jejudo Island, present study).

\section{Molecular identification}

To confirm and verify the accuracy of the morphological species identification, we also analyzed 634 base pairs of the mitochondrial COI gene. The DNA sequence of the specimen was almost identical to a previously published sequence (GU188480) of $F$. scriptissimus (genetic distance, $d=0.003$ ). The $\mathrm{NJ}$ tree also clustered the specimen with the GenBank sample of F. scriptissimus, with a strong $100 \%$ bootstrap value (Fig. 4).

\section{Discussion}

The specimen in question has all the previously reported diagnostic morphological characters of $F$. scriptissimus, including five bifurcate pelvic fin rays, 20 vertebrae, 13 pectoral fin rays, and a basidorsal ocellus on the side of the body (Table 1 and Fig. 2). The form of the esca as a simple, oval-shaped appendage with numerous, more or less parallel, vertically aligned folds also matches the morphology of $F$. scriptissimus. Additionally, the form of the membrane behind the second dorsal spine matches F. scriptissimus, by lacking division into naked dorsal

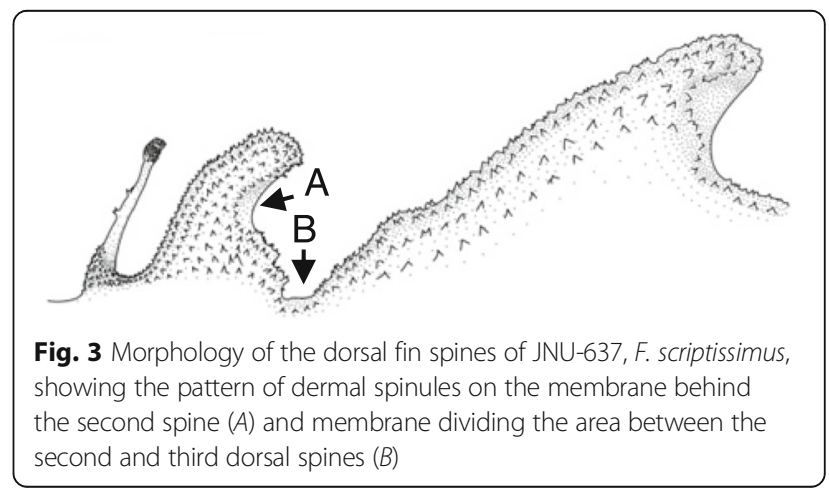




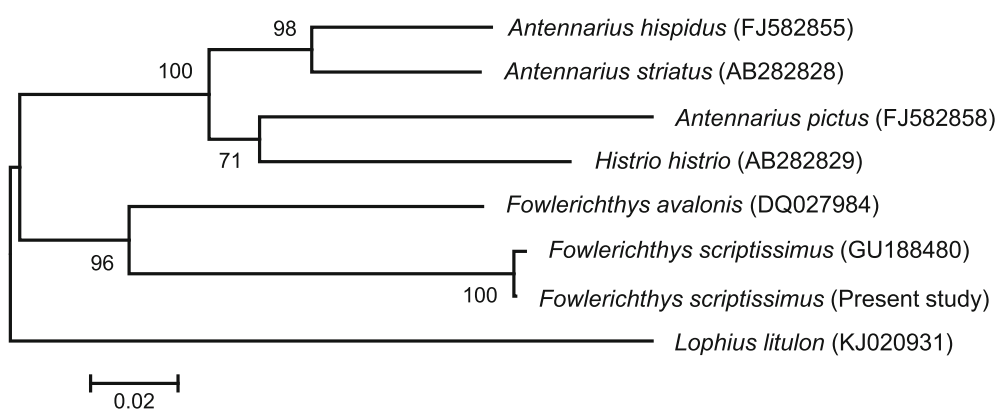

Fig. 4 Neighbor-joining tree showing the relationship of the specimen with the seven species of anglerfishes. Numbers above nodes indicate bootstrap probabilities based on 10,000 replications. Bar indicates a K2P genetic distance of 0.02

and ventral portions, extending posteriorly to the area between the second and third dorsal spines, and nearly reaching to the base of the third spine (Fig. 3). Thus, the morphological characteristics of the specimen clearly fit the species descriptions given by previous studies (Table 1). In the molecular analysis of the mitochondrial COI gene, the small genetic distance $(d=0.003)$ between the new specimen and a previously sequenced specimen of $F$. scriptissimus, and the close clustering of those two samples in a neighbor-joining tree (Fig. 4) including the seven anglerfish species confirmed the morphological identification. Thus, both morphological and molecular approaches indicated the specimen in the present study to be F. scriptissimus.

The genus Fowlerichthys was firstly suggested when Barbour (1941) described Fowlerichthys floridanus, but his description and diagnosis of the genus were unclear. He mentioned that the strong and sharp dorsal spines of the species were unlike the dorsal fin rays in the species of Antennarius, but whether these spines were bare in life is difficult now to determine certainly. Thus, most ichthyologists have regarded the genus Fowlerichthys as a synonym of Antennarius. Recently, Arnold and Pietsch (2012) demonstrated that Fowlerichthys is a valid genus that can be separated from Antennarius by having all five pelvic fin rays bifurcate (all other antennariids have four simple and one bifurcate rays). It can be further separated from all members of Antennarius except Antennarius commerson by possessing 20 vertebrae (Table 2). Currently, the genus Fowlerichthys is recognized as valid, with five known species worldwide Fowlerichthys radiosus, F. avalonis, Fowlerichthys senegalensis, Fowlerichthys ocellatus, and F. scriptissimus (Froese and Pauly 2016).

F. scriptissimus is easily distinguished from the other Korean frogfishes (A. pictus, A. commerson, A. maculatus, and $H$. histrio) by having 13 pectoral fin rays (vs. 10 in A. commerson, 11 in A. maculatus, 10 in A. pictus, and 10 in $H$. histrio), five bifurcate pelvic rays (vs. one in the genus Antennarius and none in $H$. histrio), and 20 vertebrae (vs. 19 in $H$. histrio and all members of Antennarius except A. commerson) (Table 2).

We propose new Korean names, "Byeol-ssin-beng-i-sok" and "Byeol-ssin-beng-i" for the genus and species, respectively. The Korean name "Byeol-ssin-beng-i" was given for $F$. scriptissimus because of its scattered beige spots on the body that look alike stars. The Korean words "byeol" and "ssin-beng-i" mean star and frogfish, respectively.

\section{Conclusions}

Not applicable.

Table 2 Comparison in the number of pectoral fin rays, bifurcate pelvic fin rays, and vertebrae among five frogfish species inhabiting Korea

\begin{tabular}{lllll}
\hline Species & Pectoral fin rays & Bifurcate pelvic rays & Vertebrae & References \\
\hline F. scriptissimus & 13 & 5 & 20 & Pietsch and Grobecker (1987) \\
A. commerson & $10-11$ (usually 11) & 1 & $19-20$ (usually 19) \\
A. maculatus & $10-11$ (usually 10) & 1 & 19 \\
A. pictus & $9-11$ (usually 10) & 1 & 19 \\
H. histrio & $9-11$ (usually 10) & 0 & $18-19$ (usually 19) & \\
\hline
\end{tabular}




\section{Abbreviations}

COI: Cytochrome c oxidase subunit 1; d: Genetic distance

\section{Acknowledgements}

This work was supported by a grant from the National Institute of Fisheries Science (R2016034). We thank Prof. B. Sidlauskas, Oregon State University, for the valuable discussion.

\section{Funding}

This study was funded by a grant from the National Institute of Fisheries Science (R2016034)

\section{Availability of data and materials}

All datasets generated during and/or analyzed during the current study are available from the corresponding author on reasonable request.

\section{Authors' contributions}

$\mathrm{SHH}$ performed experiment and wrote the manuscript. JSK collected the sample. CBS conceived of the study and helped to write the manuscript. All authors read and approved the final manuscript.

\section{Competing interests}

The authors declare that they have no competing interests.

\section{Consent for publication}

Not applicable.

\section{Ethics approval and consent to participate}

Not applicable.

\section{Author details}

${ }^{1}$ Jeju Fisheries Research Institute, National Institute of Fisheries Science, Jeju 63068, Korea. Korea Fisheries Resources Agency, Jeju Branch, Jeju 63005,

Korea. ${ }^{3}$ College of Ocean Sciences, Jeju National University, Jeju 63243, Korea.

Received: 10 August 2016 Accepted: 2 February 2017

Published online: 17 February 2017

\section{References}

Araga C. Family Antennarioidae. In: Masuda H, Amaoka K, Araga C, Uyeno U, Yoshino T, editors. The fishes of the Japanese Archipelago. Tokyo: Tokai Univ Press; 1984. p. 102-3.

Arnold RJ, Pietsch TW. Evolutionary history of frogfishes (Teleostei: Lophiiformes: Antennariidae): a molecular approach. Mol Phylogenet Evol. 2012. doi:10.1016/j.ympev.2011.09.012.

Barbour T. Notes on pediculate fishes. Proc New England Zool Club. 1941;19:7-14. Froese R, Pauly D, editors. FishBase. World Wide Web electronic publication. www.fishbase.org, version (10/2016); 2016.

Hall TA. BioEdit: a user-friendly biological sequence alignment editor and analysis program for Windows 95/98/NT. Nucleic Acids Symp Ser. 1999;41:95-8.

Hubbs CL, Lagler KF. Fishes of the Great Lakes region. Bull Granbrook Inst Sci. 1964:26:19-27.

Jordan DS. A review of the pediculate fishes or anglers of Japan. Proc US Nat Mus. 1902. doi:10.5479/si.00963801.24-1261.361.

Kim IS, Choi Y, Lee CL, Lee YJ, Kim BJ, Kim JH. Illustrated book of Korean fishes. Seoul: Kyo-Hak Publishing; 2005. p. 615.

Kim BY, Kim MJ, Song CB. First record of the frogfishes Antennarius pictus (Antennariidae, Lophiiformes). Korean J Ichthyol. 2011:23:168-71.

Kimura M. A simple method for estimating evolutionary rates of base substitutions through comparative studies of nucleotide sequences. J Mol Evol. 1980;16:111-20.

Manilo LG, Bogorodsky SV. Taxonomic composition, diversity and distribution of coastal fishes of the Arabian Sea. J Ichthyol. 2003;43:S75-S149.

Nelson JS. Fishes of the world. 4th ed. New Jersey: Wiley; 2006. p. 601.

Pietsch TW. The genera of frogfishes (family Antennariidae). Copeia. 1984 doi:10.2307/1445032.

Pietsch TW. Antennariidae. In: Randall JE, Lim KKP, editors. A checklist of the fishes of the South China Sea, Raffles Bull Zool Suppl, vol. 28. 2000. p. 569-667.

Pietsch TW, Grobecker DB. Frogfishes of the world: systematics, zoogeography, and behavioral ecology. California: Stanford Univ Press; 1987. p. 420.
Senou H. Antennariidae. In: Nakabo T, editor. Fishes of Japan with pictorial keys to the species. Tokyo: Tokai Univ Press; 2002. p. 454-8.

Stewart AL. Family Antennariidae. In: Roberts CD, Stewart AL, Struthers CD, editors. The Fishes of New Zealand, vol. 3. 2015. p. 577-1152.

Tamura K, Stecher G, Peterson D, Filipski A, Kumar S. MEGA6: molecular evolutionary genetics analysis version 6.0. Mol Bio Evol. 2013;30:2725-9.

Thompson JD, Higgins DG, Gibson TJ. CLUSTAL W: improving the sensitivity of progressive multiple sequence alignment through sequence weighting, position specific gap penalties and weight matrix choice. Nucl Acids Res. 1994;22:4673-80.

\section{Submit your next manuscript to BioMed Central and we will help you at every step:}

- We accept pre-submission inquiries

- Our selector tool helps you to find the most relevant journal

- We provide round the clock customer support

- Convenient online submission

- Thorough peer review

- Inclusion in PubMed and all major indexing services

- Maximum visibility for your research

Submit your manuscript at www.biomedcentral.com/submit 